\title{
NOTES ON THE BIRDS OF THE WOLLASTON LAKE REGION, SASKATCHEWAN, SUMMER, 1977
}

D. M. SECOY, Biology Department, University of Regina, Regina, Saskatchewan. S4S OA2 and ERIC MAW, Zoology Department, University of Alberta, Edmonton, Alberta. T6G 2E2

In the field work preceeding the writing of The Birds of Northeastern Saskatchewan, one of the areas visited by Nero and his assistants to determine the southern limits of the transitional zone of the boreal forest was the Wollaston Lake region. ${ }^{5}$ An opportunity arose for us to visit the region in the summer of 1977. Maw spent the entire summer, 28 May to 16 August, in the area observing birds and collecting insects and plant specimens. Secoy visited the area from 13 to 15 July. The summer base was a Department of Mineral Resources camp located on Boland Lake, a small lake at the southwest margin of Wollaston Lake (Fig. 1).

Regular traverses were made in the vicinity of Boland Lake to determine the species present and gain some information on the productivity of the area. Flights into a number of other small lakes, named in Fig. 1, allowed additional field work within the area from $57^{\circ} 30^{\prime}$ to $58^{\circ} 00^{\prime} \mathrm{N}$ and $103^{\circ} 00^{\prime}$ to $104^{\circ} 00^{\prime} \mathrm{W}$.

As Nero has noted, there is a variety of habitats in the Wollaston Lake region. ${ }^{5}$ South of Wollaston, rock outcrops are few, much of the area being covered by compact sand. Black Spruce predominates in both open and closed stands, with an admixture of Jack Pine. The proportion of pine and the density of trees varies with fire history, age of stand and drainage conditions. A few limited, higher, dry areas are occupied by persistant pure stands of Jack Pine. The extensive low-lying areas are covered primarily by sprucesphagnum bog. Birch, alder, willows and some spruce line the banks of small water courses and lake shores. Dense stands of emergent Sedge (Carex sp.) occur in shallow bays and protected lake margins. The mouths of the many slow-moving streams support large, dissected Sedge-Buckbean (CarexMenyanthes) floating marshes. A large esker forms the eastern margin of Boland Lake, with signs of bear, wolf and caribou attesting to its use as a trail.

Of the 77 species seen in the summer of 1977, 21 had not been reported by Nero from this area. These species are indicated by an asterisk $\left({ }^{*}\right)$. No specimens were collected.

\section{Species List}

COMMON LOON. Common. Seen from 28 May to 8 August. A pair on each small lake and several on the larger lakes. Three nests of small heaps of grasses or sedge found on lakeshore margins, each with either 2 eggs or chicks. First downy young seen 27 June, the last 29 July. One nest lost to a seiche (change in water level). Immatures first seen 6 August. Response to an overflight by a Bald Eagle consisted of both adults calling and one circling on the water near the young with its wings spread.

AMERICAN BITTERN*. Singles seen or heard from 30 May to 26 June in shoreline marshes of Boland Lake. 

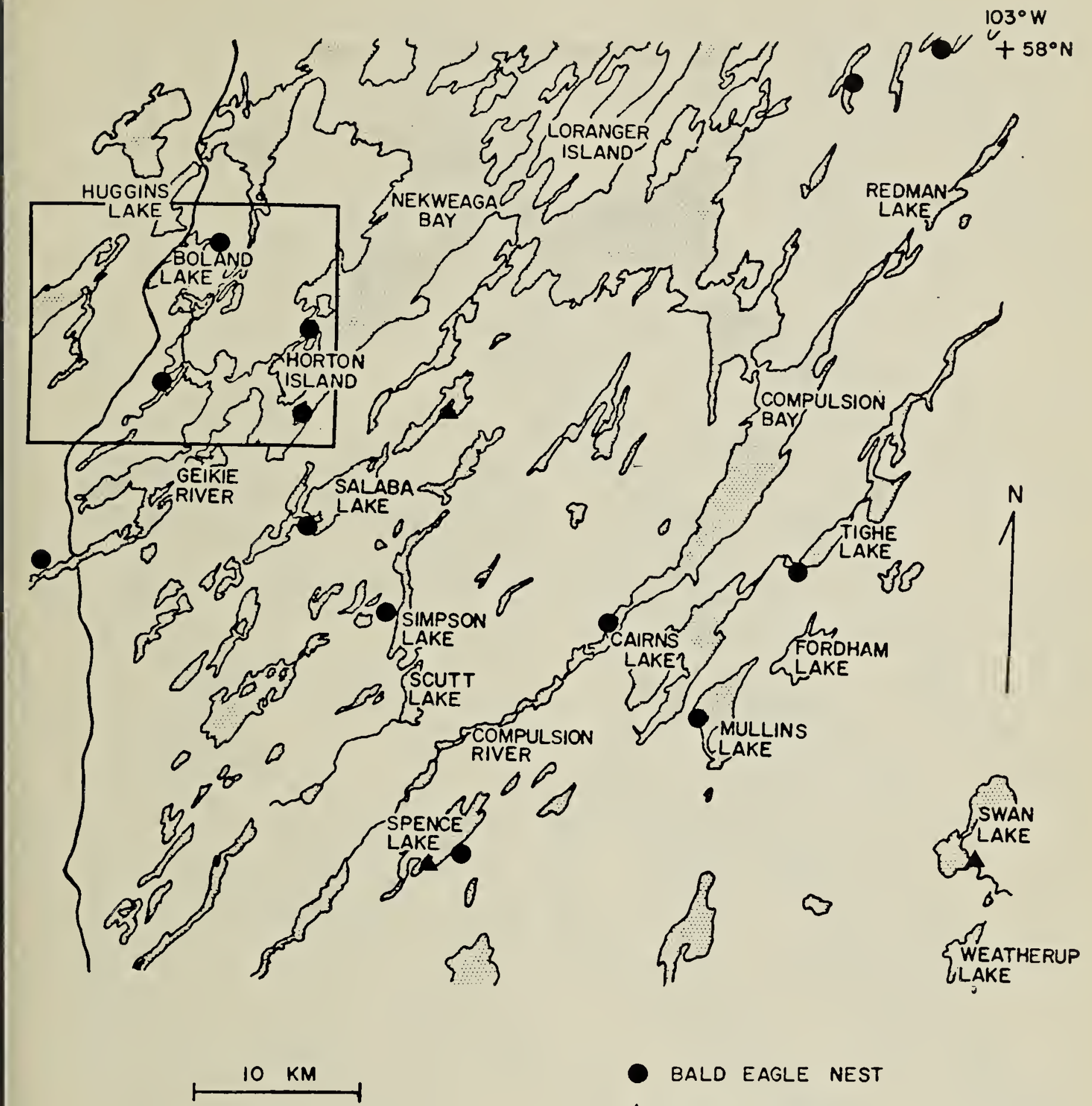

- bald eAgle nest

$\triangle$ OSPREY NEST

Figure 1. Map of the southern end of Wollaston Lake, showing the lakes mentioned in the text. Known Bald Eagle and Osprey nests are indicated. The area outlined is shown in greater detail in Figure 2.

CANADA GOOSE. Groups of 2 to 100 flew in from Wollaston Lake to feed around Boland Lake throughout the summer.

MALLARD. Seen from 4 June to 16 August around Boland Lake. Four broods known (nests with. 10 and 11 eggs, two broods of 7 and 9 downy young). Known hatching dates were 15 June and 2 July.

AMERICAN GREEN-WINGED TEAL. On 13 June, 6 males feeding in sedge marshes on shore of Boland. Single female flushed on a small pond nearby.
BLUE-WINGED TEAL.* Singles, pairs and small groups of males (2-7) from 12 June to 16 August on Boland.

AMERICAN WIGEON. Pair feeding in marsh on Boland Lake 5 June.

GREATER SCAUP.* A pair of ducks seen 13 July on a pond near the large esker were identified as this species. The birds were feeding and grooming so that there was ample opportunity for both Maw and Secoy to note the characteristic light primary stripe and the sharp distinction between dark breast 


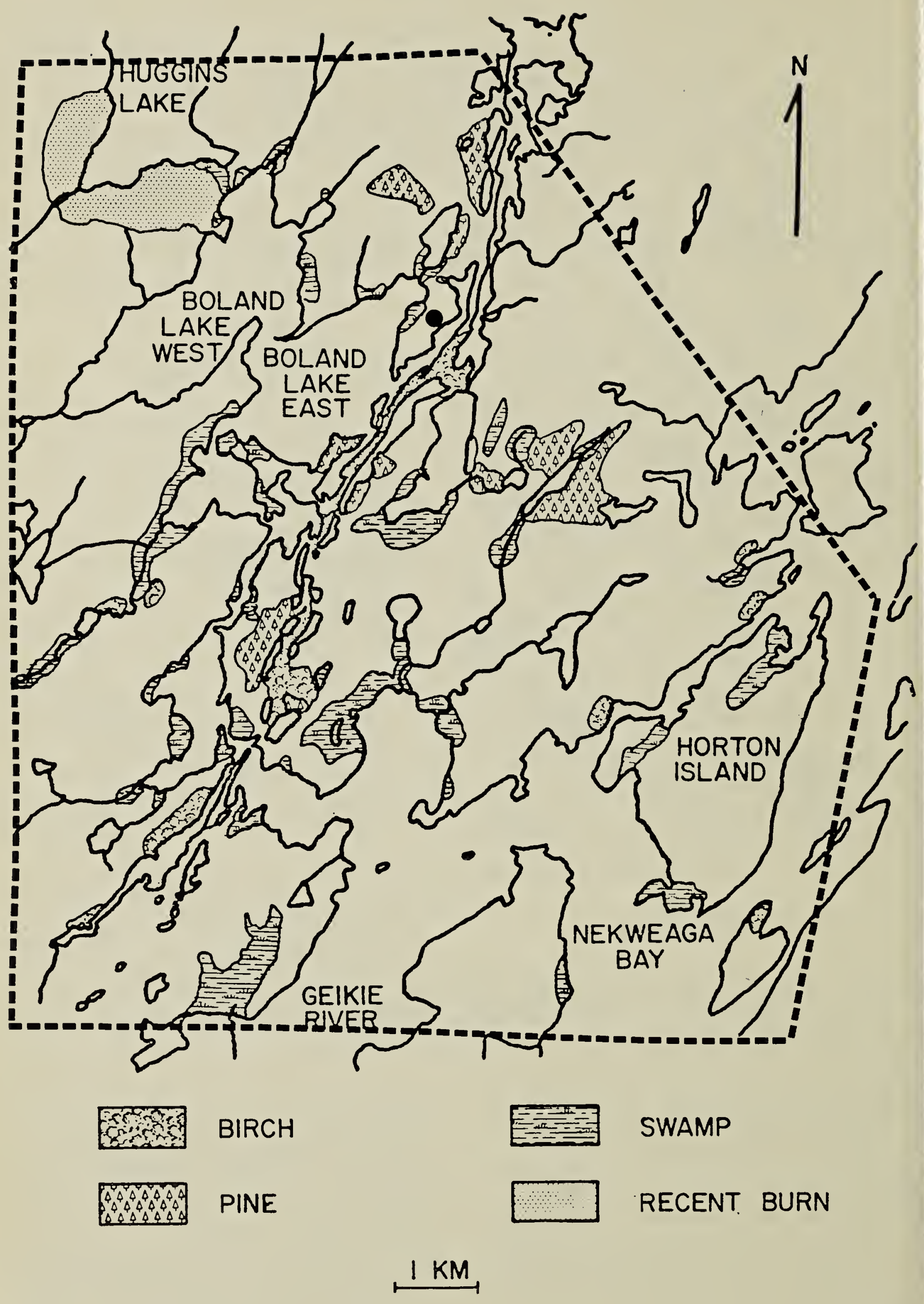

Figure 2. Map of the Boland Lake camp area. Unless indicated otherwise, the area within the outline is covered with spruce, either in pure stands or mixed with pine or birch. The camp site is indicated by a circle. 
and light side and belly on the male. Head colour could not be distinguished. This species has been considered in recent times to occur in Saskatchewan only as a sporadic, occasional migrant. Houston and Street believed the species to be erratic in northern Saskatchewan. ${ }^{3}$ Nero discussed them as a possible breeder in the Lake Athabasca region and northern Saskatchewan. ${ }^{4}$

LESSER SCAUP. Smali groups (1-5) of males on several lakes between 1 June and 10 July. Pair seen 7 July on Boland Lake.

BUFFLEHEAD. Seen from 7 June to 5 August. Four broods of $4,6,7$, and 11 young seen on small ponds in the area. One brood known to hatch 20 June.

WHITE-WINGED SCOTER. Pair and 2 large young on Boland 13 July. Six on another smali lake 25 July.

SURF SCOTER. Courtship on Boland Lake 5 June. Two broods, of 6 and 8 downy young on small pond 7 July near Mullins Lake. A group of 6 immatures on Swan Lake 29 July.

COMMON MERGANSER. Three males and 6 females in the rapids of a small stream entering Boland Lake 7 June. One shore-line nest of a shallow grass-lined depression with 6 eggs at Mullins Lake was destroyed by a seiche 5 July. Downy young in broods of 6 and 9 were seen 24 and 26 July, the latter in the lowest rapids of the Geikie River. Groups $(4,7)$ of large immatures seen 24 and 26 July.

RED-BREASTED MERGANSER. Several pairs and small groups $(2,5)$ of females on Boland from 5 June to 16 July.

GOSHAWK.* A temale and 2 young seen a number of times during the summer along the north shore of Boland. Fed on Spruce Grouse and Northern Waterthrush (?). Chased by Common Terns; chased a large buteo (Red-tailed Hawk?).

RED-TAILED HAWK. One adult seen at Lake, $58^{\circ} \mathrm{N} 103^{\circ} \mathrm{W}, 23$ July; one near Boland 5 August. One possible 4 August near Boland Lake, chased by Goshawk.

BALD EAGLE. Bald Eagles seen at 13 places during the summer (see Fig. 1). Nine nests found; at least 4 were active. One nest with 1 young, others with 2. Boland Lake nest with 2 young: downy 17 June; by 20 June sitting on the edge of the nest and one-half the size of the adults; complete juvenal feathering by 14 July; not seen to fly. Young from another nest flying by 6 August. Young fed on rabbits and fish. In conflict with Osprey, American Kestrel, Herring Gulls, Common Terns, Ravens and Redwinged Blackbirds, all of which dominated the eagles.

MARSH HAWK.* A pair on Boland hunted through the summer over the marshes. Four seen playing over spruce woods east of Boland 27 July (pair plus 2 young?). Single animal over the same spruce woods 27 July.

OSPREY. Ospreys were seen at four lakes, but no young seen (Fig. 1).

MERLIN. Dead male at Mullins Lake 7 July.

AMERICAN KESTREL. On 29 July, male chased a Bald Eagle near the lowest rapids on the Geikie River.

SPRUCE GROUSE. Seen in every area visited. Chicks seen from 16 June until early July, young first seen flying on 13 July. Total of 12 broods with 1-7 young (av. 3.75).

SORA.* One at Boland 12 June in large marsh. On 15 June, found nest lined with sedges, and eggs (12) matching description in Harrison in same marsh. ${ }^{2}$

COMMON SNIPE. Singles seen from 12 June to 10 August in Carex-salix marshes around Boland. Pair seen 24 July.

SPOTTED SANDPIPER. Single birds on the camp dock, sporadically through the summer. Pairs seen in streams in the area. Single bird on rocks on shore of Mullins Lake 8 July.

SOLITARY SANDPIPER. Singles feeding and apparently defending nests in black spruce bogs at several small lakes through the summer.

GREATER YELLOWLEGS. Pairs and groups of 8 and 14 at several lakes 4-14 June. In July, nest defense behaviour of calling and circling flight in spruce bogs.

LESSER YELLOWLEGS. Seen sporadically from 13 June to 25 July at Boland and 
Mullins Lakes feeding in shallow marshes.

WHITE-RUMPED SANDPIPER.* A small sandpiper feeding in the mud at Boland Lake 2 July had a white rump and upper tail coverts and is tentatively identified as this species.

BAIRD'S SANDPIPER.* Five small sandpipers flying over a marsh near Boland Lake 8 August are tentatively identified as this species.

WILSON'S PHALAROPE.* Seen several times in June and July in the Boland Lake area. Singles of both sexes, pairs, and a pair with immature were seen. This is a northward extension from the typical breeding range in the prairie sloughs, although they have also been reported in boreal lakes farther south (Kazan Lake). ${ }^{6}$

HERRING GULL. Nesting in the lakes which had exposed rocky islands, such as Redman and Swan. Seen nesting in trees at Mullins Lake. Downy young seen from 8 to 29 July.

MEW GULL. Seen through the summer at Boland, Huggins and Mullins Lakes. Three empty stick nests found at Huggins Lake 30 June.

BONAPARTE'S GULL. Seen sporadically over the summer at Boland and small lakes in the vicinity, and the river between Cairns and Tighe Lakes. Seen resting in spruce bogs and hawking over the lake surface after emerging mayflies.

COMMON TERN. Small groups (1-4) at Boland and small lakes in the area from 28 May to 10 August.

ARCTIC TERN.* Single bird on the large marsh at Boland Lake 12 June.

BOREAL OWL.* Pair found roosting in an abandoned raven's nest on a cliff south of Scutt Lake 15 June.

COMMON NIGHTHAWK. Courtship seen on an open sandy area near camp 6 June with 6 males courting a single female. A nest south of Boland Lake in an open pine stand had 2 eggs on 22 June. The female flew around a $20-\mathrm{m}$ circle of the nest while it was being examined. A second nest 1 July had a pipped egg and a wet young. Females with a dis- traction display of spread, fluttering wings and clicking croak. Another female with fledged young 22 July used the same display.

BELTED KINGFISHER. Two burrows found at Boland Lake, at least one occupied. Birds seen also at Salaba and Swan Lakes, Nekweaga Bay and the lowest rapids on the Geikie River.

COMMON FLICKER. Pair seen sporadically through the summer in the spruce stands at the north end of Boland Lake raised a brood which were seen as immatures 7 August. Other birds were seen in spruce south of Boland and near Swan Lake.

NORTHERN THREE-TOED WOODPECKER. Single females and pairs in spruce or birch stands at Boland, Spence, Huggins and Swan Lakes. On 19 June, a pair seen feeding 2 young in a hole in a nearly dead birch at Spence Lake.

YELLOW-BELLIED FLYCATCHER.* Single bird in pine and birch woods on the spine of the esker 5 August.

OLIVE-SIDED FLYCATCHER. Single males singing in the tops of sentinel spruces from 8 July to 2 August at Swan, Boland, Mullins and Tighe Lakes. Immature seen 2 August.

TREE SWALLOW. Seen sporadically through the summer from late May to 17 August at Boland, Mullins and Tighe Lakes.

BARN SWALLOW.* Three flying over the dock 15 June; single bird over the dock 16 July.

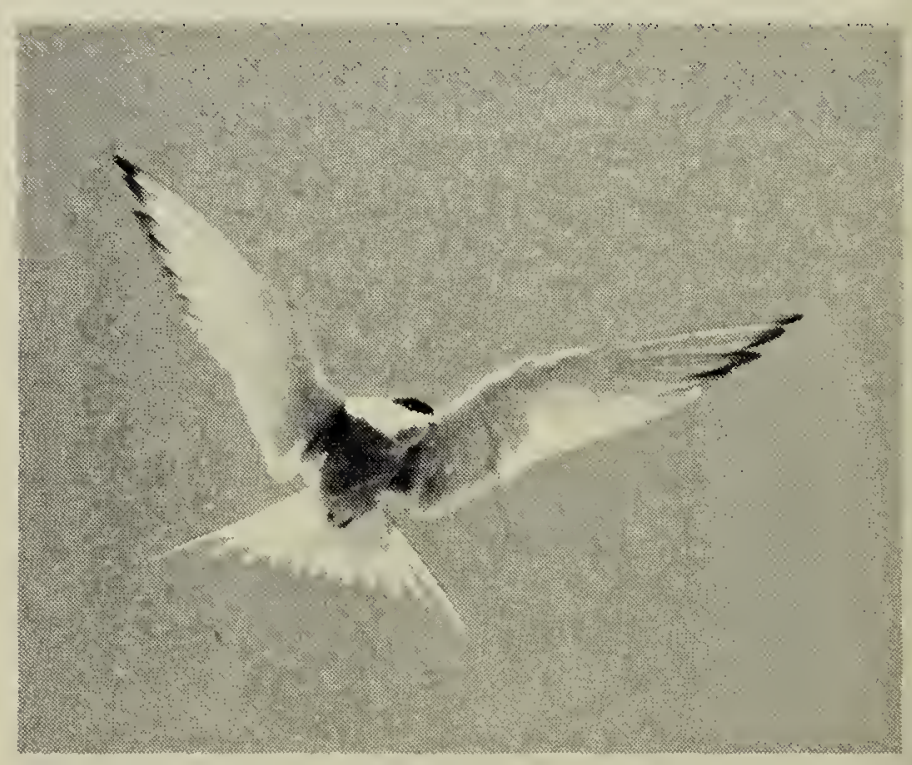

Arctic Tern

Wayne Lynch 
GRAY JAY. Common in the area. Newly fledged young seen from 4 June to 23 July. Immature seen from 8 July to 5 August, in groups of up to 6 .

COMMON RAVEN. Seen sporadically in groups of 1-7 from 31 May to 17 August at Boland, Huggins and Cairns Lakes. Pair in a nest 16 August at Huggins Lake but no young seen.

BOREAL CHICKADEE. Individuals and pairs seen sporadically at Boland and Salaba lakes. Two immatures 2 August.

RED-BREASTED NUTHATCH.* Single male feeding along the trunk of a black spruce 27 July near Boland Lake.

AMERICAN ROBIN. One at Boland Lake in late May.

HERMIT THRUSH. One singing at Huggins Lake 30 June

SWAINSON'S THRUSH. Singing males were first heard 1 June. Only nest found at Boland Lake had 4 eggs in a nest of lichens, grass and sphagnum in a Black Spruce 16 June. Eggs had hatched before a second visit 20 June. Immatures seen by 28 July.

RUBY:CROWNED KINGLET. Seen at Boland, Mullins and Fordham lakes in spruce groves. Courtship seen 8 June. Young first seen 1 July. Three broods of 4, 4, and 3-4 seen. Independent immatures present 30 July. Seen to feed on mosquitoes and caddisflies.

WATER PIPIT. One on the shore on Boland Lake 17 June.

WARBLING VIREO.* Single bird heard and seen in dry pine-spruce woods along the esker at Boland Lake 24 June.

TENNESSEE WARBLER, Common at Boland Lake from 12. June to 27 July. Also seen at Muilins Lake. Range of habitats from spruce bogs to birch and alder thickets. Immatures seen 27 July.

YELLOW WARBLER. Seen at Boland and Mullins lakes in shoreline vegetation, whether spruce or birch. Immature seen 5 August. One male heard in antiphonal song with a Magnolia Warbler.

MAGNOLIA WARBLER.* Singing males seen throughout June in pine, spruce and spruce-birch woods around Boland Lake.
YELLOW-RUMPED WARBLER. Common. Seen at all lake areas visited. Eight broods known around Boland Lake, with 1 to 6 immatures seen together. Fledglings seen from 25 June to 2 August (indicating possible second or late nesting). Birds fed on spiders, mayflies, caddisflies, sawfly larvae, geometrid caterpillars and noctuid moths.

BAY-BREASTED WARBLER.* Male singing in a black spruce near camp 4 June.

BLACKPOLL WARBLER. Pair in alder at Spence Lake 19 June.

PALM WARBLER. Seen sporadically from 19 June, when a singing male was seen in a stand of young pine in a burned spruce bog at Spence Lake, until 2 August, when an immature was feeding in spruce at Boland Lake.

NORTHERN WATERTHRUSH. Single singing male in top of black spruce 4 June; apparently killed by Goshawk.

WILSON'S WARBLER.* Single male in a dense willow thicket at Mullins Lake 6 July.

YELLOW-HEADED BLACKBIRD.* Single male with a flock of Red-winged Blackbirds in the marshes along the edge of Boland Lake 13 June. This species has only been reported north to Kazan Lake and the Churchill River previously. ${ }^{6}$

RED-WINGED BLACKBIRD. Seen only on sedge marshes in the shallows on Boland Lake. First seen 12 June, with first nest, containing 5 eggs, found 15 June. Hatching 17 June. Hatching in other nests 14 and 24 July. Birds from last nest flying by 8 August. Fed on mayflies, caddisflies, dragonflies and caterpillars.

RUSTY BLACKBIRD. Pair apparently raised a brood at Boland Lake since they were seen sporadically from 26 June to 6 August, when an immature was seen with them. Single male at Mullins Lake 8 July.

PINE GROSBEAK.* Single male feeding in spruce woods near camp 15 June. Two males and 1 female feeding in open Jack Pine-Black Spruce near Boland on 1 July. Nero did not report them but noted the possibility of their using open 
woodland in this area of the boreal forest for breeding. ${ }^{5}$ The presence of both sexes at this time of year suggest breeding but no nests or immatures were seen.

WHITE-WINGED CROSSBILL. * Mixed flocks of adults and immatures seen 22 June to 23 July several places in the area. Fed in spruce stands on cones, buds and aphid galls.

SAVANNAH SPARROW. Several pairs in the willows along the large marshes at Boland Lake in June and July.

DARK-EYED JUNCO. Seen throughout the summer in most areas, from 4 June to 7 August. The first, weakly flying young were seen 16 June. The numbers of young in broods varied from 1-4, with 2 the most common. Found in spruce or spruce-pine-birch stands, feeding on caddisflies and mayflies.

CHIPPING SPARROW. Seen in a variety of habitats, from single willows in sedge marshes to dense spruce stands, in most of the areas visited. Nest-building and nest-defense seen throughout June but no young were seen until 6 August when 2 broods of 4 each were seen. Fed on mayflies and sawfly larvae.

WHITE-CROWNED SPARROW. Seen at Spence Lake 19 June and Tighe Lake 15 July in pine and open spruce.

WHITE-THROATED SPARROW. Heard at Mullins Lake 6 July and Boland Lake 13 July in pine stands.

LINCOLN'S SPARROW. Pairs seen at Boland Lake 27 June and 1 July in spruce stands.

SWAMP SPARROW. One in alders in a marsh near Boland Lake 8 June.

SONG SPARROW. Seen at several lakes between 19 June and 6 August. Young first seen 8 July. Fed on caddisflies and mayflies

\section{Species Diversity}

Species diversity and abundance in this area can be inferred from the number of birds seen and heard in a 7 $\mathrm{km}$ walk along the shore of Spence
Lake on 19 June, between 0915 and 1730. The shore was mostly occupied by spruce bog, with some spruce groves and open marsh. The total number of individuals of each species seen during the traverse is given in parentheses.

Common Loon (1); Red-breasted Merganser (1); Bald Eagle (1); Osprey (1); Spruce Grouse (10); Herring Gull (1); Northern Three-Toed Woodpecker (4); Gray Jay (3); Ruby-crowned Kinglet (1); Yellow-rumped Warbler (10); Palm Warbler (1); Blackpoll Warbler (1); Dark-eyed Junco (5); Chipping Sparrow (5); White-crowned Sparrow (1); Song Sparrow (1).

\section{Acknowledgements:}

Funds for this work were provided by the Saskatchewan Museum of Natural History and the University of Regina. Dr. J. Lewry, Department of Geology, University of Regina, kindly provided camp space and a place on flights to the various lakes. Ross D. MacCulloch drew the map.

1 GODFREY, W. E. 1966. The Birds of Canada. National Museum of Canada. Bull. 203. 428 pp.

${ }^{2}$ HARRISON, C. 1978. A field guide to the nests, eggs and nestlings of North American birds. Collins, Toronto. 416 $\mathrm{pp}$.

${ }^{3}$ HOUSTON, C. S. and M. G. STREET. 1959. The birds of the Saskatchewan River: Carlton to Cumberland. Spec. Publ. No. 2, Sask. Nat. Hist. Soc. 205 pp.

${ }^{4}$ NERO, R. W. 1963. Birds of the Lake Athabasca region, Saskatchewan. Spec. Publ. No. 5, Sask. Nat. Hist. Soc. $143 \mathrm{pp}$.

${ }^{5}$ NERO, R. W. 1967 . The birds of northeastern Saskatchewan. Spec. Publ. No. 6, Sask. Nat. Hist. Soc. 96 pp.

${ }^{6}$ RANDALL, T. E. 1962. Birds of the Kazan Lake region, Saskatchewan. Blue Jay 20: $60-72$. 